\title{
Comparing different methods of human breast milk fortification using measured $v$. assumed macronutrient composition to target reference growth: a randomised controlled trial
}

\author{
Gemma McLeod $^{1 *}$, Jill Sherriff ${ }^{2}$, Peter E. Hartmann ${ }^{3}$, Elizabeth Nathan ${ }^{4}$, Donna Geddes ${ }^{3}$ and Karen Simmer ${ }^{1}$ \\ ${ }^{1}$ School of Paediatrics and Child Health, Centre for Neonatal Research and Education, The University of Western Australia, \\ Perth, WA 6009, Australia \\ ${ }^{2}$ Nutrition and Dietetics, School of Public Health, Curtin Health Innovation Research Institute, Curtin University, Perth, \\ WA 6845, Australia \\ ${ }^{3}$ School of Chemistry and Biochemistry, The University of Western Australia, Perth, WA 6009, Australia \\ ${ }^{4}$ Women and Infants' Research Foundation, Carson House, King Edward Memorial Hospital, Perth, WA 6008, Australia
}

(Submitted 15 December 2014 - Final revision received 6 October 2015 - Accepted 22 October 2015-First published online 2 December 2015)

\begin{abstract}
The variable content of human breast milk suggests that its routine fortification may result in sub-optimal nutritional intakes and growth. In a pragmatic trial, we randomised infants born below 30 weeks of gestation to either the intervention (Igp) of fortifying milk on measured composition according to birth weight criteria and postmenstrual age (PMA) or our routine practice (RPgp) of fortifying on assumed milk composition to target $3.8-4.4 \mathrm{~g}$ protein $/ \mathrm{kg}$ per $\mathrm{d}$ and $545-629 \mathrm{~kJ} / \mathrm{kg}$ per d. Milk composition was measured using the MIRIS® Human Milk Analyser. Percentage fat mass (\%FM) was measured using PEA POD (COSMED). The effects of macronutrient intakes and clinical variables on growth were assessed using mixed model analysis. Mean measured protein content $(1.6 \mathrm{~g} / 100 \mathrm{ml})$ was higher than the assumed value $(1.4 \mathrm{~g} / 100 \mathrm{ml})$, often leading to lower amounts of fortifier added to the milk of intervention infants. At discharge (Igp $v$. RPgp), total protein (3.2 (sD 0.3) $v .3 .4$ (SD 0.4 ) g; $P=0.067$ ) and energy ( 456 (SD 39) $v .481$ (sD 48) kJ; $P=0.079$ ) intakes from all nutrition sources, weight gain velocity (11.4 (sD 1.4$) v .12 \cdot 1$ (sD $1 \cdot 6$ ) $\mathrm{g} / \mathrm{kg}$ per $\mathrm{d} ; P=0 \cdot 135$ ) and $\% \mathrm{FM}$ (13.7 (sD 3.6) $v .13 .6$ (sD 3.5) \%; $P=0.984$ ) did not significantly differ between groups. A protein intake $>3.4 \mathrm{~g} / \mathrm{kg}$ per $\mathrm{d}$ reduced \%FM by $2 \%$. Nutrition and growth was not improved by targeting milk fortification according to birth weight criteria and PMA using measured milk composition, compared with routine practice. Targeting fortification on measured composition is labour intensive, requiring frequent milk sampling and precision measuring equipment, perhaps reasons for its limited practice. Guidance around safe upper levels of milk fortification is needed.
\end{abstract}

Key words: Protein intakes: Protein:energy: Body composition: Human milk fortification

In the past decade and a half, there has been universal recognition that increased amounts of protein and energy are necessary to address the nutrition and growth deficits that accrue postnatally in preterm infants. In attempts to address this, parenteral amino acids and lipid are delivered earlier and more aggressively after preterm birth, and also the protein and energy contents of breast milk are increased through the routine addition of human breast milk fortifier, using an assumed milk composition. Despite these strategies, preterm infants often receive less protein and energy than they need ${ }^{(1)}$, which is concerning, as growth and composition of weight gain can be influenced by the macronutrient composition of the $\operatorname{diet}^{(2,3)}$, and recent studies suggest that at term-equivalent age, preterm infants have altered and increased adiposity and increased amounts of ectopic lipids, compared with their peers ${ }^{(4,5)}$.
Although international consensus guidelines suggest that energy intakes should be based on birth weight criteria (<1000 g: 545-629 kJ/kg per d; 1000 to $<1500$ g: $461-545 \mathrm{~kJ}$ ) and recommend reducing protein with increasing postmenstrual age $(\mathrm{PMA})^{(6)}$, European guidelines base protein recommendations on body weight and suggest that energy intakes exceeding $565 \mathrm{~kJ} / \mathrm{kg}$ per d ( $135 \mathrm{kcal} / \mathrm{kg}$ per d) may promote fat deposition rather than accretion of lean tissue ${ }^{(7)}$ (Table 1).

Attempts to improve nutritional and growth outcomes by trialling different fortification regimens have provided mixed results $^{(8-10)}$. Polberger et al. ${ }^{(8)}$ fortified milk with human milk (HM) protein ( $n$ 16) or bovine fortifier $(n$ 16) to provide a targeted protein intake of $3.5 \mathrm{~g} \mathrm{~kg} / \mathrm{kg}$ per $\mathrm{d}$, based on infant weight, volume intake (150-170 $\mathrm{ml} / \mathrm{kg}$ per $\mathrm{d})$, feed tolerance

Abbreviations: \%FM, Percentage fat mass; FFM, fat-free mass; HMF, human milk fortifier; Igp, intervention group; KEMH, King Edward Memorial Hospital; MOM, mothers own milk; PER, protein:energy; PMA, postmenstrual age; RPgp, routine practice group.

* Corresponding author: G. McLeod, fax +61 89340 1266, email gemma.mcleod@health.wa.gov.au 
Table 1. Protein and energy guidelines*

\begin{tabular}{|c|c|c|c|}
\hline \multicolumn{2}{|l|}{ Consensus Guidelines $2005^{(6)}$} & \multicolumn{2}{|c|}{ ESPGHAN Guidelines $2010^{(7)}$} \\
\hline Criteria & & Criteria & \\
\hline 24-30 week PMA & & Body weight $<1000 \mathrm{~g}$ & \\
\hline Protein & $3.8-4 \cdot 4$ & Protein & $4.0-4.5$ \\
\hline PER & $3 \cdot 3-3 \cdot 4$ & PER & $3 \cdot 6-4 \cdot 1$ \\
\hline 30-36 week PMA & & Body weight $1000-1800 \mathrm{~g}$ & \\
\hline Protein & $3 \cdot 4-4 \cdot 2$ & Protein & $3.5-4.0$ \\
\hline PER & $2 \cdot 8-3 \cdot 3$ & PER & $3 \cdot 2-3 \cdot 6$ \\
\hline \multicolumn{4}{|l|}{ 36-40 week PMA } \\
\hline Protein & $2 \cdot 8-3 \cdot 4$ & & \\
\hline PER & $2 \cdot 4-2 \cdot 8$ & & \\
\hline Energy & & Energy & \\
\hline Birth weight $<1000 \mathrm{~g}$ & $545-629 \mathrm{~kJ}$ & Body weight $1000-1800 \mathrm{~g}$ & $461-565 \mathrm{~kJ}$ \\
\hline Birth weight 1000 to $<1500 \mathrm{~g}$ & $461-545 \mathrm{~kJ}$ & & \\
\hline
\end{tabular}

ESPGHAN, European Society for Paediatric Gastroenterology, Hepatology and Nutrition; PMA, postmenstrual age; PER, protein:energy.

${ }^{*}$ All values are expressed in $\mathrm{kg} / \mathrm{d}$ except PER (g protein/419 kJ).

and measured protein content of the milk. They found no significant differences in growth or biochemical outcomes between groups. de Halleux et al. ${ }^{(9,11)}$ measured milk composition and fortified the milk of twenty-four very low birth weight infants each for at least 3 weeks duration from 2006 through to 2011 using a bovine whey protein fortifier and a fat supplement and demonstrated less variation in protein intake than would be achieved theoretically with routine fortification. Arslanoglu et $a l^{(10)}$ did not measure milk composition but demonstrated that in adjusting the fortifier based on plasma urea using a commercially prepared, bovine-based fortifier, infants gained more weight than those who received routine fortification. However, protein intakes for all infants were significantly and consistently lower than the recommended intakes ${ }^{(1)}$. Some of these studies have been of short duration, a variety of products and methods have been used to fortify the milk, differences and improvements in growth outcomes have not been consistently shown and body composition, which has emerged as a necessary measure of nutrition adequacy, has not been assessed.

We conducted a randomised pragmatic study to test the hypothesis that growth and body composition of preterm infants more closely matches intra-uterine growth ${ }^{(12,13)}$ if fortification based on measured milk composition is used to target consensus protein intakes according to PMA and energy intakes according to birth weight (Table 1) rather than using an assumed milk composition to target upper limits of consensus protein $\left(3 \cdot 8-4.4 \mathrm{~g} / \mathrm{kg}\right.$ per d) and energy (545-629 $\mathrm{kJ} / \mathrm{kg}$ per d) intakes ${ }^{(6)}$.

\section{Methods}

\section{Recruitment criteria}

In total, forty infants born below 30 weeks of gestation admitted to the neonatal intensive care unit (NICU) at King Edward Memorial Hospital (KEMH) in Western Australia were recruited for the study period (January 2009-June 2009) from birth to nearterm PMA if they were born without congenital abnormalities, if maternal intention was to feed HM and if living remotely would not prevent participation at all assessments. This age criterion was implemented because all infants born below 30 weeks of gestation admitted to the KEMH NICU are given parenteral nutrition (PN) as first fluids. At this gestational age, a weight of $1000 \mathrm{~g}$ corresponds to the 10th percentile on Fenton's growth chart and our routine practice targets the consensus energy recommendation for infants weighing $<1000 \mathrm{~g}$ at birth. The primary outcomes for this trial were weight, length, head circumference, weight gain velocity ${ }^{(14,15)}$ and percentage fat mass (\%FM) measured using air displacement plethysmography (PEA POD; COSMED) at discharge/corrected term. The secondary outcomes reported elsewhere ${ }^{(16)}$ were sub-cutaneous adipose and muscle tissue measurements taken by ultrasound. Transfer of infants ( $n$ 21) during the study from tertiary to Level 2 outlying nurseries within a $30-\mathrm{km}$ radius of the KEMH did not interrupt the study protocol; infants continued to participate in the trial to completion. Comparisons between 'transferred' $v$. 'not transferred' infants showed no baseline differences and no growth outcome differences within each treatment group. The Ethics Committees at both KEMH and The University of Western Australia reviewed and approved the study protocol. Written informed consent was obtained from the infants' mothers before commencing the study. The trial was registered with the Australian New Zealand Clinical Registry (http://www.anzctr.org.au) as ACTRN12610000443099; UTNU1111-1115-4183.

\section{Randomisation and blinding}

Infants were randomised to the intervention (individualised fortification based on measured composition according to birth weight criteria and PMA) or routine practice (routinely optimised fortification based on assumed composition to target $3 \cdot 8-4.4 \mathrm{~g}$ protein $/ \mathrm{kg}$ per d; $545-629 \mathrm{~kJ} / \mathrm{kg}$ per d (130-150 $\mathrm{kcal} / \mathrm{kg}$ per $\mathrm{d}$ )), and the allocation ratio was $1: 1$. Twins were randomised as individuals. The randomisation sequence was achieved by random draw, without replacement (G. M.). Group allocation was concealed in sequentially numbered, opaque, sealed envelopes, which remained unopened until parental consent had been obtained and infant demographics had been recorded (research nurse or G. M.). Parents and the clinical teams managing the care of infants (including making the clinical decisions, prescribing each infant's daily fluid intake 
and fortification status and maintaining clinical records) were blinded to group allocations. Allocated nursing staff in the centralised milk room at KEMH, and in the outlying hospitals, were responsible for collecting and freezing the milk samples before fortification and for adding fortifier to the milk as per the study protocol. The chief investigator (G. M.) was responsible for the following: (i) conducting the milk analysis; (ii) calculating the weekly mean composition of each infant's milk and the amount of fortifier to be added to the milk of intervention infants; (iii) providing fortification instructions to nursing staff for all study participants, (iv) data collection; and (v) ensuring the study protocol was understood and maintained.

\section{Milk sampling and analysis}

Mother's milk was fed in the order in which it was expressed for at least the first $14 \mathrm{~d}$ of enteral feeding, and extending up to the first $28 \mathrm{~d}$ if available for infants born below 26 weeks of gestation. Any residual samples of early frozen milk not used before an infant was receiving fresh milk were added to feeds over time, as needed. Therefore, each infant's daily native milk feed was made up from their own mothers' individual and pooled collections of expressed milk and may have included milk expressions from different days. A well-mixed sample $(3-6 \mathrm{ml})$ of each infant's daily milk feed (mothers own milk (MOM) or donor human milk (DHM)) was collected before fortification by nursing staff and labelled and frozen at $-20^{\circ} \mathrm{C}$ $\left(-5^{\circ} \mathrm{C}\right.$ for outlying Level 2 nurseries). Each batch of weekly samples was gathered and analysed in the Human Milk Bank laboratory at the end of each week by G. M. The samples were defrosted, warmed in a water bath to $40^{\circ} \mathrm{C}$, homogenised ( $1.5 \mathrm{~s} / \mathrm{ml}$ of sample; Sonics Vibra-Cell, Model VCX-130; Sonics and Materials Inc.) and the protein, fat and lactose concentrations were determined using the MIRIS® (human milk analyser (HMA): processed milk setting). The method has been described and evaluated elsewhere ${ }^{(17,18)}$. For each week that fortified feeds were prescribed for an infant, the weekly mean content of the infant's milk samples from the previous week was used to fortify the infant's milk feeds for the following week.

\section{Fortification methods}

A commercial multi-component human milk fortifier (HMF) (Wyeth Nutritionals), a protein powder (Beneprotein; Novartis) and an energy supplement (Duocal; SHS International Limited) were used to fortify milk feeds.

Milk for the intervention infants (Igp) was fortified with variable amounts of these fortifiers (HMF: maximum $4 \mathrm{~g} / 100 \mathrm{ml}$; Beneprotein: maximum 0.5 g/100 ml; Duocal: maximum $3.0 \mathrm{~g}$ / $100 \mathrm{ml}$ ), depending upon measured milk composition and fluid status (fluid-restricted $130-150 \mathrm{ml} / \mathrm{kg}$ per d; non-fluid-restricted $160-180 \mathrm{ml} / \mathrm{kg}$ per d). Protein was first adjusted and then, if necessary, energy supplemented to best achieve targets.

Milk for the infants fed according to routine practice (RPgp) was fortified in fixed dose amounts (HMF $4 \mathrm{~g} / 100 \mathrm{ml}$ for non-fluid-restricted infants; HMF $4 \mathrm{~g} / 100 \mathrm{ml}+$ Beneprotein $0.5 \mathrm{~g} / 100 \mathrm{ml}+$ Duocal $2.5 \mathrm{~g} / 100 \mathrm{ml}$ for fluid-restricted infants) using an assumed composition derived from published ${ }^{(19)}$ and unpublished macronutrient milk analysis of preterm milk conducted in our Unit (protein 1.4\%; fat 4.4\%; lactose 6.8\%). Our assumed composition falls within the published range of data describing preterm macronutrient composition of milk expressed over the first 1-2 months of lactation ${ }^{(20-23)}$.

\section{Nutrition}

Until the initiation of fortified milk feeds, all infants were fed according to the Unit's standard feeding regimen.

Parenteral nutrition. On day 1 of life, 5 or $7.5 \%$ glucose and $1.5 \%$ amino acids were infused until day 2 , when individualised PN including lipids $(20 \%, 1.0 \mathrm{~g} / \mathrm{kg}$ per d), electrolytes and micronutrients was commenced. Subsequently, concentrations and rates were increased, targeting recommended intakes ${ }^{(6)}$.

Enteral nutrition. Minimal enteral feeds, using frozen MOM in the sequence in which it was expressed, were initiated as early as possible after birth and increased following a standardised regimen. PN was simultaneously reduced. If MOM was unavailable, pasteurised DHM was available for the infants until at least a postmenstrual age of 34 weeks. As per unit guidelines and using clinical discretion, the medical teams prescribed fortification once enteral volumes $\geq 100 \mathrm{ml} / \mathrm{kg}$ per $\mathrm{d}$ were achieved, and ceased fortification just prior to discharge.

\section{Nutrition intake during hospital stay}

All fluid and intakes consumed during hospital stay were recorded retrospectively from the observation charts from midnight on day 1 of life until the discharge measurements. The milk volume consumed during a breast-feeding session was estimated to be equivalent to that amount normally given at a scheduled feeding session unless a top-up was also given, in which case the estimated volume taken during the breastfeeding session was calculated by subtracting the volume of the top-up from the scheduled feed volume. Macronutrient intakes were calculated using composition data of daily milk feeds obtained for both groups with the HMA, and energy intakes were derived using the Atwater values $(\mathrm{kJ} / \mathrm{g}$ ( $\mathrm{kcal} / \mathrm{g})$ ) for protein 16 (4), fat 37 (9) and lactose 16 (4), adopted by the National Health and Medical Research Council ${ }^{(24)}$.

\section{Body composition}

\%FM measurements were obtained at discharge ( $n$ 32) or on transfer to outlying Level 2 nurseries ( $n$ 8) using air displacement plethysmography (PEA POD). The technical design and the methodology underpinning a PEA POD measurement have been described elsewhere ${ }^{(25,26)}$. In brief, the PEA POD utilises the classic two-compartment BC model to measure infants weighing between 1 and $8 \mathrm{~kg}$. Total body density is calculated from the direct measurements of body mass (electronic scale) and volume (air displacement). The software provided by COSMED incorporates algorithms to derive percent body fat and fat-free mass (FFM). These algorithms use the constant fat mass (FM) density value of $0.9007 \mathrm{~g} / \mathrm{ml}$ and predetermined FFM density values modelled using the data of Fomon et al. ${ }^{(13)}$. 


\section{Gestational age and postmenstrual age}

Gestational age was calculated as the time elapsed from the date of the first day of the last menstrual period to delivery. If the date of the last menstrual period was unknown, the modified Ballard method was used. PMA was calculated according to the following formula: gestational age + postnatal age (time elapsed after birth).

\section{Anthropometry}

In accordance with the Neonatal Clinical Care Unit's (NCCU) measurement policy, weight $(\mathrm{g})$, measured in the infant's incubator or with digital scales (SECA, $10 / 20 \mathrm{~kg}$; $d=5 / 10 \mathrm{~g}$ or PEA POD), crown-heel length and occipital-frontal head circumference were measured at birth, discharge and at term PMA. Fenton's data were used to convert measurements to $z$-scores ${ }^{(27)}$. Infants requiring intensive care (NICU) were also weighed daily, and those in special care were weighed twice weekly, with daily weight derived by interpolation between each of the time points. Weight gain velocity was calculated using an exponential model that has been validated in preterm infants $^{(14,15)}$.

\section{Statistical analysis}

Descriptive statistics for continuous data were summarised using means and standard deviations or medians, interquartile ranges and ranges. Categorical data were summarised using frequency distributions. Univariate comparisons of continuous clinical data, nutritional intakes and anthropometric measures were conducted using one-sample $t$ tests, independent $t$ tests or Mann-Whitney tests according to normality, and $\chi^{2}$ or Fisher's exact tests were used for categorical comparisons. Reliability of \%FM measurements for PEA POD was determined by calculating the standard deviation, $\mathrm{CV}$ and technical error. The technical error was defined as $\sqrt{ } \Sigma d^{2} / 2 n$, where $d$ is the difference between two repeated tests for the paired observations. Comparisons of $\mathrm{BC}$, measured as percentage body FM, were assessed at discharge using linear regression modelling after adjustment for PMA, weight $z$-score at measurement and residuals from a linear regression of length on weight at time of measurement. Linear mixed models analysis was conducted to produce growth curve models for weight gain velocity to discharge. A natural logarithm transformation was applied to the outcome to achieve normality, as indicated by residual diagnostics. Protein, carbohydrate and fat intakes and clinical variables were assessed for their effects on the rate of growth. Adjustment was made for birth weight $z$-score, PMA at the time of measurement and chronological age. SAS 9.1 of the SAS System for Windows, Copyright ${ }^{\odot}$ 2002-2010 SAS Institute Inc. and PASW ${ }^{\circledR} 17$ statistical software (SPSS Inc.), was used for data analysis. All tests were two-tailed, and $P$ values $<0.05$ were considered statistically significant.

\section{Power}

Estimation of sample size was based on data from a previous audit $^{(28)}$ using a mean growth rate of 12.8 (SD 5) g/kg per $\mathrm{d}$. A sample size of 20 in each group was sufficient to achieve $80 \%$ power to detect a difference of $3.4 \mathrm{~g} / \mathrm{kg}$ per $\mathrm{d}$ in a repeated measures design with an alpha level of 0.05 (Power Analysis and Sample Size Statistical Software 2008).

\section{Results \\ Subject demographics}

Ninety-one infants admitted to the NCCU between 26 January and 9 June 2009 were born below 30 weeks of gestation. Fifty-one infants were excluded from the study for reasons including congenital renal abnormality $(n 1)$, withheld consent ( $n$ 8), living remotely ( $n$ 13), paused recruitment (due to an investigator's absence) ( $n$ 19) and death ( $n$ 10; Fig. 1$)$. Forty infants (Caucasian $n$ 36, Australian Aboriginal: Igp $n$ 1, RPgp $n$ 1; Asian: RPgp $n$ 1, Other: RPgp $n$ 1) born from either singleton ( $n$ 24) or twin ( $n$ 16) births at a median age of 27 (range 23, 29) weeks and a birth weight of 1022 (range 480-1475) g were randomly assigned to the intervention ( $n$ 20) or routine practice ( $n$ 20). Siblings from two sets of twin births were each randomly allocated to the same group $\left(n_{1}=\right.$ both twins randomised to Igp; $n_{2}=$ both twins randomised to RPgp), otherwise siblings were randomly allocated to different groups. The clinical characteristics of the infants did not significantly differ between groups (Table 2). All infants were appropriate for gestational age (10th percentile to 90th percentile), with the exception of two infants fed routinely, whose birth weights were on the 6th weight percentile. The corrected PMA ranges of infants in the intervention and routine practice groups measured at discharge were 33-43 and 33-42 weeks, respectively.

\section{Composition of milk feeds}

The mean values and standard deviations of measured protein, fat and lactose concentrations and the derived energy content and protein:energy (PER) of milk feeds ( $n 1870$ samples) were similar for both groups (Table 3).

\section{Nutritional intakes and growth outcomes}

On average, $17 \%$ by volume of the total fluids received by infants while in hospital were given intravenously and human milk constituted $93 \%$ of the enteral intakes (84\% MOM: Igp $n$ 18, RPgp $n$ 19; $16 \%$ DHM: Igp $n$, RPgp $n$ 4), and an estimated $7 \%$ of MOM was breast-fed. Unfortified milk feeds were suspended for one intervention infant for a period of $30 \mathrm{~d}$ when PN was provided due to suspected necrotising enterocolitis (Stage 2 NEC) ${ }^{(29)}$. Fortified feeds were prematurely ceased and not re-instituted for two intervention infants (feed intolerance $n_{1}=$ day $15 ; n_{2}=$ day 47$)$ and for two infants fed according to routine practice $\left(n_{1}=\right.$ Stage $2 \mathrm{NEC}^{(29)}$ day $14 ; n_{2}=$ cows' milk protein intolerance day 32 ). One intervention infant did not receive fortifier and transitioned directly from unfortified milk to preterm formula, due to the unavailability of DHM. In total, eleven infants (Igp: $n$ 6, RPgp: $n$ 5) received some infant formula during their hospital stay. The number of days infants consumed fortified milk did not differ between groups (Igp: $n$ 19: 44 (SD 24) $v$. RPgp: $n$ 20: 42 (SD 23) d; $P=0.801$ ), and per study protocol protein $(3.2(\mathrm{sD} 0.4) v .3 .9(\mathrm{sD} 0.3) \mathrm{g} / \mathrm{kg}$ per d; $P<0.001)$ and energy (510 (sD 39) v. 559 (sD 34) kJ/kg per $\mathrm{d} ; P<0.001)$ 


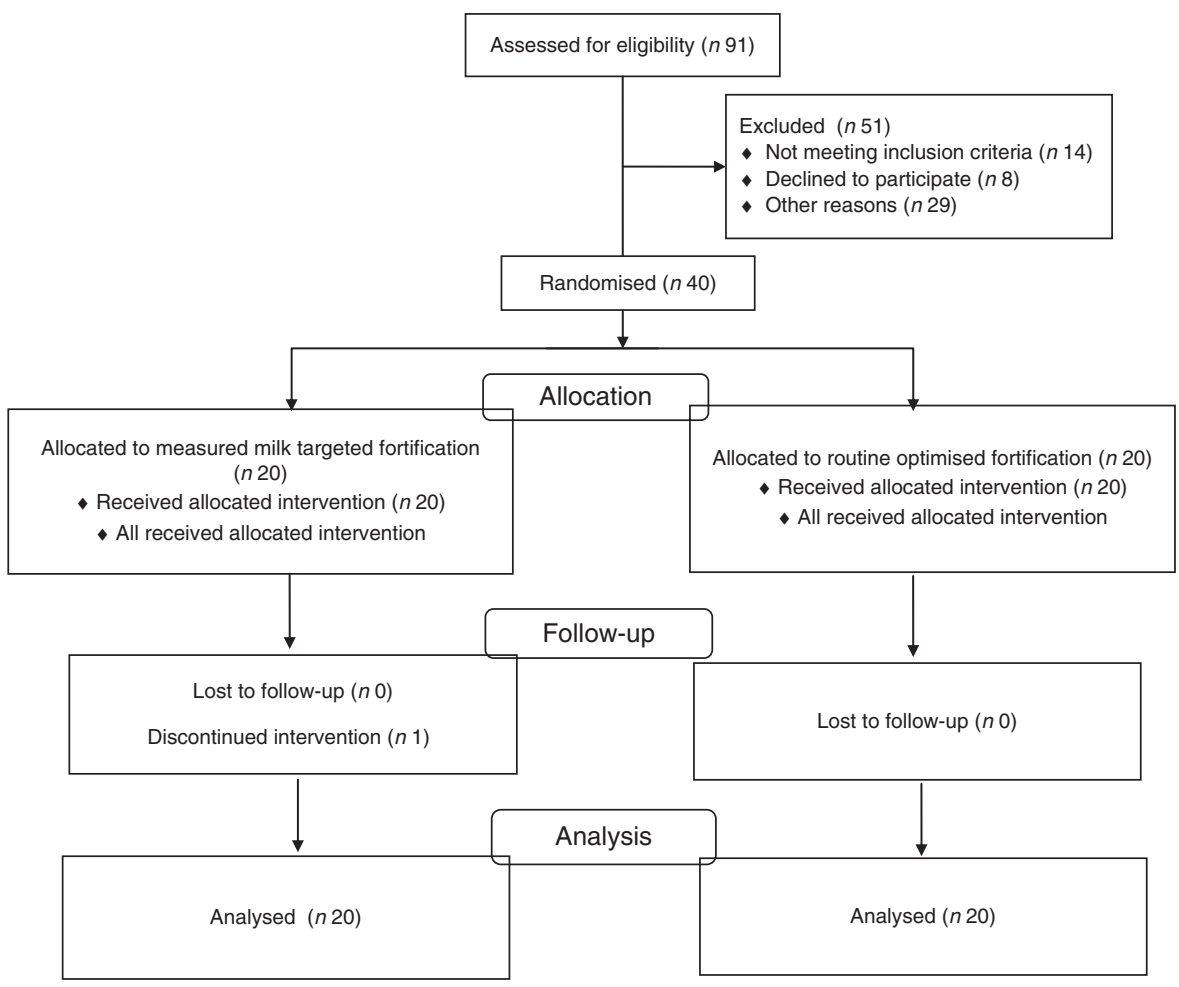

Fig. 1. Enrolment and participation.

intakes from fortified milk were lower in the intervention infants than in those fed according to routine practice (Table 3). Intention-to-treat analysis showed that after fortification (i.e. once infants made the initial transition from unfortified milk) total protein and energy intakes and the PER did not significantly differ between groups (Table 3). At discharge, weight $(\mathrm{g})$, length $(\mathrm{cm})$, head circumference $(\mathrm{cm})$ and weight gain velocity were similar between groups (Table 4); eighteen infants had weights below the 10th percentile (Igp: $n$ 11, RPgp: $n 7 ; P=0 \cdot 204)$.

When adjusted for corrected PMA, chronological age and birth weight $z$-score, no significant difference in weight gain velocity was found between groups ( $P=0 \cdot 140$; Table 5). There was an average $9 \%$ increase in weight gain velocity $(\mathrm{g} / \mathrm{kg}$ per d) for every additional $\mathrm{g} / \mathrm{kg}$ per $\mathrm{d}$ of enteral protein $(95 \% \mathrm{CI}$ $1,18 ; P=0.024)$.

At discharge, rates of weight gain achieved by each group were significantly slower than the fetal rate (birth to discharge: Igp: $P<0.001$; RPgp: $P<0.001$; and after recovery of birth weight to discharge: Igp: $P<0 \cdot 001$; RPgp $P=0.051$ ).

\section{Body composition}

At discharge (Igp: 38 (sD 2) weeks; RPgp: 38 (sD 2) weeks), both groups had similar \%FM, both univariately and after adjusting for PMA and length at measurement $(P=0.269$; Table 5). Female infants had an average 3\% greater FM than males $(95 \%$ CI 1,$5 ; P<0.001)$. After inclusion of carbohydrate in the regression model, a protein intake $>3.4 \mathrm{~g} / \mathrm{kg}$ per $\mathrm{d}$ (from all nutrition sources) reduced FM by $2 \%(P=0 \cdot 042)$. The energy intakes of the ten infants (Igp: $n$ 4, RPgp: $n$ 6; $25 \%$ ) who consumed these higher protein intakes ranged between 389 and $537 \mathrm{~kJ} / \mathrm{kg}$ per $\mathrm{d}$, and their mean rate of weight gain, calculated after recovery of birth weight, was similar to the fetal rate (high protein: $14.7 \mathrm{~g} / \mathrm{kg}$ per $\mathrm{d} v$. fetal: $15 \mathrm{~g} / \mathrm{kg}$ per $\mathrm{d}$; $P=0.514)$.

At discharge, preterm infants had a significantly greater mean \%FM for age than the reference fetus values (Igp: 13.7 (sD 3.6) \%; $P<0.001$, RPgp: 13.6 (sD 3.5) \%; $P<0.001 v$. reference fetus: $9 \cdot 5 \%)^{(12)}$.

\section{Discussion}

The fortification design used in this pragmatic clinical trial did not improve growth or body composition outcomes of infants born below 30 weeks of gestation compared with those fed according to routine practice. The method of fortifying human breast milk on measured composition, targeting consensus protein and energy intakes for corrected PMA and birth weight criteria was labour intensive and time consuming and did not prove a superior method over fortifying milk on assumed composition in fixed dose amounts to target upper consensus limits for the extremely low birth weight infant. There are mitigating reasons for these outcomes. First, the milk protein content measured using MIRIS was higher ( $1.6 \mathrm{~g}$ ) compared with the assumed value ( $1.4 \mathrm{~g})$, and as a result lower amounts of fortifier were often added to the milk of intervention infants. Two studies designed to evaluate the accuracy and precision of the MIRIS measurement have shown that the HMA 
Table 2. Clinical data

(Numbers and percentages; mean values and standard deviations; medians and ranges)

\begin{tabular}{|c|c|c|c|c|c|}
\hline & \multicolumn{2}{|c|}{$\operatorname{lgp}(n 20)$} & \multicolumn{2}{|c|}{$\operatorname{RPgp}(n$ 20) } & \multirow[b]{2}{*}{$P$} \\
\hline & $n$ & $\%$ & $n$ & $\%$ & \\
\hline \multicolumn{6}{|l|}{ Gestational age (weeks) } \\
\hline Mean & $27 \cdot 0$ & & $27 \cdot 1$ & & 0.781 \\
\hline SD & 1.9 & & $2 \cdot 0$ & & \\
\hline Median & 26 & & 27 & & 0.752 \\
\hline Range & $23-29$ & & $23-29$ & & \\
\hline \multicolumn{6}{|l|}{ Birth weight (g) } \\
\hline Mean & $1014 \cdot 8$ & & $1009 \cdot 2$ & & 0.953 \\
\hline SD & $269 \cdot 3$ & & $313 \cdot 1$ & & \\
\hline Median & 1022 & & 1009 & & 0.752 \\
\hline Range & $560-1475$ & & $480-1375$ & & \\
\hline \multicolumn{6}{|l|}{ Birth length $(\mathrm{cm})$} \\
\hline Mean & $35 \cdot 3$ & & $35 \cdot 7$ & & 0.764 \\
\hline SD & 3.5 & & 4.6 & & \\
\hline Median & 35.5 & & $36 \cdot 0$ & & 1.000 \\
\hline Range & $28 \cdot 5-41 \cdot 0$ & & $27 \cdot 0-42 \cdot 0$ & & \\
\hline \multicolumn{6}{|l|}{ Birth head circumference $(\mathrm{cm})$} \\
\hline Median & $25 \cdot 0$ & & $25 \cdot 2$ & & 0.948 \\
\hline Range & $21 \cdot 0-27 \cdot 5$ & & $20 \cdot 0-28 \cdot 0$ & & \\
\hline Median & $25 \cdot 0$ & & $25 \cdot 2$ & & 1.000 \\
\hline Range & $21 \cdot 0-27 \cdot 5$ & & $20 \cdot 0-28 \cdot 0$ & & \\
\hline Male sex & 9 & 45 & 10 & 50 & 0.752 \\
\hline Apgar $1 \mathrm{~min}<7$ & 13 & 68 & 17 & 85 & 0.273 \\
\hline Patent ductus arteriosus & 13 & 65 & 11 & 55 & 0.519 \\
\hline Necrotising enterocolitis $\leq$ stage $2^{(29)}$ & 3 & 15 & 2 & 10 & 1.000 \\
\hline Antibiotic courses $\geq 2$ & 13 & 65 & 10 & 50 & 0.337 \\
\hline Indomethacin & 8 & 40 & 7 & 35 & 0.744 \\
\hline Blood culture/s positive & 10 & 50 & 7 & 35 & 0.337 \\
\hline Blood transfusion/s & 14 & 70 & 11 & 55 & 0.327 \\
\hline \multicolumn{6}{|l|}{ Recovery of birth weight (d) } \\
\hline Median & 10 & & 10 & & 0.849 \\
\hline Range & $1-25$ & & $1-21$ & & \\
\hline \multicolumn{6}{|l|}{ Parenteral nutrition (d) } \\
\hline Median & 19 & & 17 & & 0.766 \\
\hline Range & $6-36$ & & $6-47$ & & \\
\hline \multicolumn{6}{|l|}{ Full enteral feeds achieved (d) } \\
\hline Median & 17 & & 17 & & 0.654 \\
\hline Range & $8-27$ & & $9-29$ & & \\
\hline \multicolumn{6}{|l|}{ Days from birth when feeds were fortified } \\
\hline Median & 20 & & 20 & & 0.903 \\
\hline Range & 10-39 & & $10-36$ & & \\
\hline \multicolumn{6}{|l|}{ Weight at start of fortification (g) } \\
\hline Median & 1032 & & 1155 & & 0.925 \\
\hline Range & 700-1998 & & $505-1885$ & & \\
\hline \multicolumn{6}{|c|}{ Duration of oxygen (d) $(\operatorname{lgp} n 17, \operatorname{RPgp} n 19)$} \\
\hline Median & 6 & & 28 & & 0.163 \\
\hline Range & $1-87$ & & $1-112$ & & \\
\hline \multicolumn{6}{|c|}{ Duration of ventilation and CPAP (d) (Igp $n$ 19, RPgp $n$ 20) } \\
\hline Median & 47 & & 36 & & 0.955 \\
\hline Range & $1-89$ & & $1-95$ & & \\
\hline
\end{tabular}

Igp, intervention group; RPgp, routine practice group; CPAP, continuous positive airway pressure.

overestimates milk protein by a small ${ }^{(17,18)}$, but significant ${ }^{(18)}$, amount, whereas a more recent study suggests that it systematically underestimates protein content by a similar amount ${ }^{(30)}$. As the analytical methods and milk sampling designs differed in these studies, it is difficult to assess whether there was need to make an adjustment to the measurement before calculating the amount of fortifier required to correct the protein deficit in the milk feeds of each of the infants in this trial. Menjo et al. ${ }^{(17)}$ suggest that this is a necessary strategy for clinicians, but it was not one adopted in this trial.
Another confounder in this study is that fortification was not adjusted to compensate for the dilutionary effect of breast-feeding (although contributing only an estimated $7 \%$ to milk intake), making continued titration of protein potentially superfluous after breast-feeding replaced one or more scheduled feeds. Furthermore, the maximum amounts of fortifier we arbitrarily permitted to be added to feeds sometimes proved limiting in achieving the desired level of fortification thought necessary to achieve the protein and energy and PER targets for an infant. 
Table 3. Macronutrient composition of milk feeds* and nutritional intakes (Mean values and standard deviations)

\begin{tabular}{|c|c|c|c|c|c|}
\hline \multirow[b]{3}{*}{ Per $100 \mathrm{ml}$} & \multicolumn{4}{|c|}{ Composition of milk feeds ( $n 1870$ samples) } & \multirow[b]{3}{*}{$P$} \\
\hline & \multicolumn{2}{|c|}{$\lg (n 20)$} & \multicolumn{2}{|c|}{ RPgp $(n$ 20) } & \\
\hline & Mean & SD & Mean & SD & \\
\hline Protein (g) & 1.6 & 0.5 & 1.6 & 0.1 & 0.466 \\
\hline Fat $(\mathrm{g})$ & 4.3 & 0.7 & 4.5 & 0.6 & 0.332 \\
\hline Lactose (g) & $6 \cdot 8$ & 0.2 & 6.9 & 0.2 & 0.133 \\
\hline Energy (kJ) & 304 & 25 & 312 & 22 & 0.290 \\
\hline \multirow[t]{4}{*}{ PER } & $2 \cdot 3$ & 0.7 & $2 \cdot 1$ & 0.3 & 0.237 \\
\hline & \multicolumn{4}{|c|}{ Calculated nutritional intakes after milk was fortified on measured composition } & \\
\hline & \multicolumn{2}{|c|}{$\operatorname{lgp}(n 20)$} & \multicolumn{2}{|c|}{$\operatorname{RPgp}(n$ 20) } & \\
\hline & Mean & SD & Mean & SD & \\
\hline Fluid (ml) & 158 & 14 & 153 & 9 & 0.256 \\
\hline Energy (kJ) & 524 & 44 & 538 & 47 & 0.336 \\
\hline Protein $(\mathrm{g})$ & 3.3 & 0.4 & 3.4 & 0.5 & 0.673 \\
\hline PER & $2 \cdot 6$ & 0.3 & $2 \cdot 7$ & 0.3 & 0.751 \\
\hline Lipid (g) & $6 \cdot 8$ & 0.9 & 6.8 & 1.0 & 0.702 \\
\hline $\mathrm{CHO}(\mathrm{g})$ & $12 \cdot 9$ & 1.1 & 13.5 & 0.9 & 0.640 \\
\hline
\end{tabular}

Calculated nutritional total intakes from parenteral, enteral (using measured milk composition) and IV nutrition

$\operatorname{lgp}(n$ 20) $\quad \operatorname{RPgp}(n$ 20)

\begin{tabular}{|c|c|c|c|c|c|}
\hline & Mean & SD & Mean & SD & \\
\hline Fluid (ml) & 147 & 8 & 146 & 8 & 0.555 \\
\hline Energy (kJ) & 456 & 39 & 481 & 48 & 0.079 \\
\hline Protein $(\mathrm{g})$ & $3 \cdot 2$ & 0.3 & 3.4 & 0.4 & 0.067 \\
\hline PER & 3.0 & 0.5 & $3 \cdot 0$ & 0.3 & 0.973 \\
\hline Lipid (g) & $5 \cdot 7$ & 0.9 & 5.9 & 0.8 & 0.372 \\
\hline $\mathrm{CHO}(\mathrm{g})$ & 11.6 & 0.9 & $12 \cdot 3$ & 1.1 & 0.026 \\
\hline
\end{tabular}

Igp, intervention group; RPgp, routine practice group; PER, protein:energy; $\mathrm{CHO}$, carbohydrate; IV, intravenous.

* Mean macronutrient composition of milk from $14 \mathrm{~d}$ of an infant commencing MEF to discharge; Atwater conversion factors: protein $16 \mathrm{~kJ} / \mathrm{g}$; fat $37 \mathrm{~kJ} / \mathrm{g}$; lactose $16 \mathrm{~kJ} / \mathrm{g}$.

Table 4. Growth data of infants at discharge

(Mean values and standard deviations)

\begin{tabular}{|c|c|c|c|c|c|}
\hline & \multicolumn{2}{|c|}{$\operatorname{lgp}(n 20)$} & \multicolumn{2}{|c|}{ RPgp control ( $n$ 20) } & \multirow[b]{2}{*}{$P$} \\
\hline & Mean & SD & Mean & SD & \\
\hline \multicolumn{6}{|l|}{ Growth at discharge } \\
\hline Age (weeks) & $37 \cdot 7$ & 2.5 & 37.8 & $2 \cdot 2$ & 0.762 \\
\hline Fat mass $(\mathrm{g})$ & 318 & 111 & 348 & 149 & 0.469 \\
\hline Body fat (\%) (without correction for length) & 13.7 & 3.6 & $13 \cdot 6$ & 3.5 & 0.984 \\
\hline Discharge weight $(\mathrm{kg})$ & 2294 & 356 & 2464 & 528 & 0.243 \\
\hline Discharge length $(\mathrm{cm})$ & 43.8 & $2 \cdot 6$ & $44 \cdot 6$ & $2 \cdot 8$ & 0.343 \\
\hline Discharge head circumference $(\mathrm{cm})$ & $32 \cdot 4$ & 1.6 & 33.1 & 1.8 & 0.184 \\
\hline Weight gain velocity from birth (g/kg per d) & 11.4 & 1.4 & $12 \cdot 1$ & 1.6 & 0.135 \\
\hline Weight gain velocity after birth weight regained $(\mathrm{g} / \mathrm{kg}$ per $\mathrm{d}$ ) & 13.4 & 1.9 & $14 \cdot 3$ & 1.6 & 0.139 \\
\hline
\end{tabular}

Igp, intervention group; RPgp, routine practice group.

Since the publication of the international consensus guidelines on which milk fortification in this study was designed ${ }^{(6)}$, the Europeans have suggested that energy intakes should be maintained between 460 and $565 \mathrm{~kJ} / \mathrm{kg}$ per d (110 and $135 \mathrm{kcal} /$ $\mathrm{kg}$ per $\mathrm{d}$ ), and protein intakes and PER should be based on a body weight range (<1000 g: PER 3·6-4.1 and 1000-1800 g: PER $3 \cdot 2-3 \cdot 6)^{(7)}$. These PER ranges, which are higher than the consensus targets $^{(6)}(2 \cdot 8-3 \cdot 3)$, are well above the PER (Igp: $2 \cdot 6$,
RPgp: 2.7) that were achieved with milk fortification in this study. They are also higher than the PER achieved by Arslanoglu et al. ${ }^{(10)}$, who demonstrated that an extra $0.8 \mathrm{~g}$ of protein powder could be added to fortified milk feeds (HMF) without adverse clinical outcomes. However, using plasma urea to guide fortification still resulted in a range of protein and energy intakes $(2.9-3.4 \mathrm{~g} / \mathrm{kg} \text { per } \mathrm{d} \text { and } 535 \mathrm{~kJ} / \mathrm{kg} \text { per } \mathrm{d})^{(1)}$ below the consensus guidelines ${ }^{(6)}$, and for protein at least values were 
Table 5. Modelling of weight gain and body composition with macronutrient intake data (Mean effects and $95 \%$ confidence intervals)

\begin{tabular}{|c|c|c|c|}
\hline Growth outcomes & Mean & $95 \% \mathrm{Cl}$ & $P$ \\
\hline \multicolumn{4}{|l|}{ Weight gain velocity* } \\
\hline Intervention group & 1.08 & $0.98,1.19$ & 0.140 \\
\hline Enteral protein $(\mathrm{g} / \mathrm{kg}$ per $\mathrm{d})$ & 1.09 & $1 \cdot 01,1 \cdot 18$ & 0.024 \\
\hline Postmenstrual age & 1.01 & $0.98,1.05$ & 0.475 \\
\hline Postmenstrual age $\mathrm{e}^{(2)}$ & 0.99 & $0.98,0.99$ & $<0.001$ \\
\hline Chronological age & 1.00 & $0.99,1.01$ & 0.164 \\
\hline Birth weight $z$-score & 0.92 & $0.86,0.99$ & 0.036 \\
\hline \multicolumn{4}{|l|}{ Percentage fat mass at discharge } \\
\hline Intervention group & 0.88 & $-0.71,2.47$ & 0.269 \\
\hline Female sex & 3.09 & $1.49,4.69$ & $<0.001$ \\
\hline Postmenstrual age age & 0.82 & $0.43,1.21$ & $<0.001$ \\
\hline Weight $z$-score & $2 \cdot 00$ & $0.93,3.08$ & 0.001 \\
\hline Residual (length $z$-score $v$. weight $z$-score) & -1.91 & $-3.26,-0.57$ & 0.007 \\
\hline \multicolumn{4}{|c|}{ Percentage fat mass at discharge (combined protein intake $>3.4 \mathrm{~g} / \mathrm{kg}$ per $\mathrm{d} v . \leq 3.4 \mathrm{~g} / \mathrm{kg}$ per d) } \\
\hline Protein $>3.4 \mathrm{~g} / \mathrm{kg}$ per $\mathrm{d}$ & -2.02 & $-3.98,-0.05$ & 0.042 \\
\hline Carbohydrate (g/kg per d) & 0.59 & $-0.23,1.41$ & 0.153 \\
\hline Female sex & $3 \cdot 21$ & $1.66,4.76$ & $<0.001$ \\
\hline Postmenstrual age & 0.63 & $0.22,1.04$ & 0.003 \\
\hline Weight $z$-score & 1.70 & $0.66,2.74$ & 0.002 \\
\hline Residual (length $z$-score $v$. weight $z$-score) & -1.85 & $-3.15,-0.54$ & 0.007 \\
\hline
\end{tabular}

below the latest European Society for Paediatric Gastroenterology, Hepatology and Nutrition (ESPGHAN) targets ${ }^{(7)}$. If the ESPGHAN recommendations ${ }^{(7)}$ are to be achieved in practice, more studies are required to determine a safe, maximum level of fortification in the context of prescribed fluid intakes, variable milk composition, fortification practices, osmolality, feeding tolerance, risk of NEC and other clinical and metabolic outcomes.

Modelled fetal chemical data suggest that the fetus more than doubles its \%FM between 33 and 42 weeks (approximately $7-16 \% \mathrm{FM})^{(12,31)}$. After achieving mean protein intakes between 3.2 and $3.4 \mathrm{~g} / \mathrm{kg}$ per $\mathrm{d}$ and energy intakes between 460 and $480 \mathrm{~kJ} / \mathrm{kg}$ per d (PER 3.0), the mean \%FM of the preterm infants in this study at the mean corrected PMA of 38 weeks was $13.7 \%$. These BC data for preterm infants accord well with \%FM estimates by Widdowson et al. ${ }^{(31)}$ of the 38 -week-old fetus $(12 \%)$ and estimates by Fomon et al. ${ }^{(13)}$ of the reference male $(13.7 \%)$ and female (14.9\%) term infants. Body composition and nutritional outcomes are difficult to measure in very preterm infants due to both the lack of suitable measuring methods in the neonatal setting and the unpredictability of an infant's clinical condition. Measuring the true effect of different fortification regimens on growth outcomes is also logistically challenging because, despite randomisation, adjusting adequately for variations in metabolic and biological responses by individuals to feeding and clinical treatments is difficult. A larger sample size, routine measurement of breast milk transfer by test-weighing and non-intrusive and accurate bedside measurement methods for measuring growth and changes in $\mathrm{BC}$ from birth would assist in addressing these difficulties and were the limitations of this study.

In this trial, the positive relationship between an achieved protein intake and \%FM suggests that fortification regimens that target higher protein intakes may improve composition of growth - a concept that should form the basis of any future study design. Current HMF are lacking sufficient protein to correct the deficit in breast milk that would facilitate the attainment of preterm nutrition and growth targets. Guidelines around safe upper limits of fortification are necessary to guide clinicians in their fortification practices. Fortifying breast milk using measured milk composition is time consuming and labour intensive, requiring precision equipment and the method may not be superior to routinely fortifying based on assumed milk composition.

\section{Acknowledgements}

The authors express their thanks and appreciation to the following people and organisations for their support: the families and infants who participated in the study; Chooi-Heen Kok, who assisted with measuring infants in the PEA POD; medical, nursing, HM banking and milk room staff at King Edward Memorial Hospital; the Women and Infants Research Foundation.

G. M. gratefully acknowledges Australian Rotary Health, The Rotary Club of Thornlie and The University of Western Australia for providing the PhD Funding Partnership Scholarship, King Edward Memorial Hospital for providing travel funding through The Post Graduate Medical Research Fund, The Stan Perron Charitable Trust that provided funds to King Edward Memorial Hospital for procurement of the PEA POD and Medela AG, which provided laboratory materials through an unrestricted research grant to The University of Western Australia.

Authors' contributions are as follows: contributions to conception and design: G. M., J. S., K. S., P. E. H.; acquisition of data: G. M., D. G.; analysis and interpretation of data: G. M., J. S., K. S., P. E. H., E. N., D. G.; drafting the article: G. M.; revising it critically for intellectual content: J. S., K. S., P. E. H., 
E. N., D. G.; final approval of the version to be published: G. M., J. S., K. S., P. E. H., E. N., D. G.

The unrestricted research grant provided to The University of Western Australia by Medela AG provides salary and associated maintenance for D. G. and supports research conducted by both D. G. and P. E. H. P. E. H has received associated honoraria from Medela AG. K. S. has presented at Nestle's Scientific Meetings and has received associated honoraria. Sponsors and those who have been acknowledged had no role in study design, data collection, analysis or interpretation of the data, writing of the manuscript or in the decision to submit the paper for publication.

Authors have not submitted this manuscript elsewhere and have no conflicts of interest to declare.

\section{References}

1. Arslanoglu S, Moro GE \& Ziegler EE (2009) Preterm infants fed fortified human milk receive less protein than they need. J Perinatol 29, 489-492.

2. Kashyap S, Forsyth M, Zucker C, et al. (1986) Effects of varying protein and energy intakes on growth and metabolic response in low birth weight infants. J Pediatr 108, 955-963.

3. Kashyap S, Schulze KF, Forsyth M, et al. (1988) Growth, nutrient retention, and metabolic response in low birth weight infants fed varying intakes of protein and energy. $J$ Pediatr 113, 713-721.

4. Uthaya S, Thomas EL, Hamilton G, et al. (2005) Altered adiposity after extremely preterm birth. Pediatr Res 57, 211-215.

5. Roggero P, Gianni ML, Amato O, et al. (2009) Is term newborn body composition being achieved postnatally in preterm infants? Early Hum Dev 85, 349-352.

6. Tsang RC, Uauy R, Koletzko B, et al. (editors) (2005) Nutrition of the Preterm Infant. Scientific Basis and Practical Guidelines, 2nd ed. Cincinnati, OH: Digital Educational Publishing Inc.

7. Agostoni C, Buonocore G, Carnielli VP, et al. (2010) Enteral nutrient supply for preterm infants: commentary from the European Society of Paediatric Gastroenterology, Hepatology and Nutrition Committee on Nutrition. J Pediatr Gastroenterol Nutr 50, 85-91.

8. Polberger S, Raiha NC, Juvonen P, et al. (1999) Individualized protein fortification of human milk for preterm infants: comparison of ultrafiltrated human milk protein and a bovine whey fortifier. J Pediatr Gastroenterol Nutr 29, 332-338.

9. de Halleux V, Close A, Stalport S, et al. (2007) [Advantages of individualized fortification of human milk for preterm infants]. Arch Pediatr 14, Suppl. 1, S5-10.

10. Arslanoglu S, Moro GE \& Ziegler EE (2006) Adjustable fortification of human milk fed to preterm infants: does it make a difference? J Perinatol 26, 614-621.

11. de Halleux V \& Rigo J (2013) Variability in human milk composition: benefit of individualized fortification in verylow-birth-weight infants. Am J Clin Nutr 98, 529S-535S.

12. Ziegler E, O'Donnell A, Nelson S, et al. (1976) Body composition of the reference fetus. Growth 40, 329-341.
13. Fomon SJ, Haschke F, Ziegler EE, et al. (1982) Body composition of reference children from birth to age 10 years. $\mathrm{Am} \mathrm{J}$ Clin Nutr 35, Suppl., 1169-1175.

14. Patel AL, Engstrom JL, Meier PP, et al. (2009) Calculating postnatal growth velocity in very low birth weight (VLBW) premature infants. J Perinatol 29, 618-622.

15. Patel AL, Engstrom JL, Meier PP, et al. (2005) Accuracy of methods for calculating postnatal growth velocity for extremely low birth weight infants. Pediatrics 116, 1466-1473.

16. McLeod G, Geddes D, Nathan E, et al. (2013) Feasibility of using ultrasound to measure preterm body composition and to assess macronutrient influences on tissue accretion rates. Early Hum Dev 89, 577-582.

17. Menjo A, Mizuno K, Murase M, et al. (2009) Bedside analysis of human milk for adjustable nutrition strategy. Acta Paediatr 98, 380-384.

18. Casadio YS, Williams TM, Lai CT, et al. (2010) Evaluation of a mid-infrared analyzer for the determination of the macronutrient composition of human milk. J Hum Lact 26, 376-383.

19. Lai C (2007) Production and Composition of Milk from 10-60 Days of Lactation in Mothers Who Delivered Prematurely. Nedlands: University of Western Australia.

20. Anderson GH, Atkinson SA \& Bryan MH (1981) Energy and macronutrient content of human milk during early lactation from mothers giving birth prematurely and at term. Am J Clin Nutr 34, 258-265.

21. Lemons JA, Moye L, Hall D, et al. (1982) Differences in the composition of preterm and term human milk during early lactation. Pediatr Res 16, 113-117.

22. Saarela T, Kokkonen J \& Koivisto M (2005) Macronutrient and energy contents of human milk fractions during the first six months of lactation. Acta Paediatr 94, 1176-1181.

23. Gross SJ, Geller J \& Tomarelli RM (1981) Composition of breast milk from mothers of preterm infants. Pediatrics $\mathbf{6 8}$, 490-493.

24. National Health and Medical Research Council (2006) Nutrient Reference Values for Australia and New Zealand Including Recommended Dietary Intakes. Canberra: Commonwealth of Australia.

25. Urlando A, Dempster P \& Aitkens S (2003) A new air displacement plethysmograph for the measurement of body composition in infants. Pediatr Res 53, 486-492.

26. Sainz R \& Urlando A (2003) Evaluation of a new pediatric air-displacement plethysmograph for body-composition assessment by means of chemical analysis of bovine tissue phantoms. Am J Clin Nutr 77, 364-370.

27. Fenton TR \& Sauve RS (2007) Using the LMS method to calculate $\mathrm{z}$-scores for the Fenton preterm infant growth chart. Eur J Clin Nutr 61, 1380-1385.

28. McLeod G, Sherriff J, Nathan E, et al. (2013) Four-week nutritional audit of preterm infants born $<33$ weeks gestation. J Paediatr Child Health 49, E332-E339.

29. Bell MJ, Ternberg JL, Feigin RD, et al. (1978) Neonatal necrotizing enterocolitis. Therapeutic decisions based upon clinical staging. Ann Surg 187, 1-7.

30. Fusch G, Rochow N, Choi A, et al. (2015) Rapid measurement of macronutrients in breast milk: how reliable are infrared milk analyzers? Clin Nutr 34, 465-476.

31. Widdowson EM (1968) Growth and composition of the fetus and newborn. In Biology of Gestation, pp. 1-49 [N Assali, editor]. New York, NY: Academic Press. 